\title{
KOMUNIKACIJA I PERFORMANSE POSLA
}

\section{COMMUNICATION AND JOB PERFORMANCE}

\author{
Vesna Milanović \\ Poslovni i pravni fakultet, „Union - Nikola Tesla“ Univerzitet, Beograd, \\ Srbija
}

\section{Nataša Bogavac-Cvetković}

Poslovni i pravni fakultet, „Union - Nikola Tesla“ Univerzitet, Beograd, Srbija

\section{Milanka Bogavac}

Poslovni i pravni fakultet, „Union - Nikola Tesla“ Univerzitet, Beograd, Srbija

CMESTE

JEL Category: M54

\begin{abstract}
Apstrakt
Komunikacija omogućava zaposlenima da efikasnije izvršavaju svoje zadatke. Zbog toga je važno da je organizacijska komunikacija efektivna. Takođe je važno da je komunikacija menadžera (komunikacija nadređenih) efektivna. Pretpostavlja se da, ako zaposleni nisu zadovoljni komunikacijom, ni njihove performanse neće biti na zadovoljavajućem nivou. Stoga je uticaj komunikacije na performanse (kao jedan od ishoda zaposlenih) testiran u raznim empirijskim studijama. Ovaj rad diskutuje o tome. Pretragom na Internetu, pronađeno je manje studija koje su posvećene uticaju komunikacije na performanse posla u odnosu na uticaj komunikacije na druge ishode zaposlenih (kao što su zadovoljstvo poslom $i$ dr.). Korišćene su ključne reči komunikacija, produktivnost, performanse posla, odnos. Rezultati potvrđuju da efektivna komunikacija povećava produktivnost. Takođe, komunikacija je dobila podršku kao prediktor performansi posla. Međutim, rezultati potvrđuju opštu vezu između ove dve varijable. U vezi s tim, svrha ovog rada je bila da pruži uvid u dimenzije komunikacije, dimenzije performansi i instrumente koji su korišćeni u važnijim empirijskim studijama. Pronađeno je da je uticaj pojedinih dimenzija komunikacije na performanse posla i njihove pojedine dimenzije nejednak. Takođe, porast zadovoljstva komunikacijom ne garantuje rast performansi (jer je veliki broj drugih faktora koji utiču na performanse). Ovo ne treba da obeshrabri dalja ispitivanja uticaja zadovoljstva komunikacijom na performanse posla, što je potvrđeno i intenziviranjem ispitivanja ovog odnosa u preduzećima manje razvijenih zemalja. U vezi s tim, od ovog rada se očekuje da pobudi istraživače na diskusiju na ovu temu i motiviše ih na dalja istraživanja uticaja komunikacije na performanse posla, a naročito u preduzećima Republike Srbije i drugih, njoj, sličnih zemalja.
\end{abstract}

Adresa autora zaduženog za korespodenciju: Vesna Milanović

Ključne reči: komunikacija, produktivnost, 䒠=vmilanovic555@gmail.com performanse posla, odnos 


\begin{abstract}
Communication enables employees to perform their tasks more efficiently. It is therefore important that organizational communication is effective. Also, it is important that managers' communication (supervisors' communication) is effective. It is assumed that if employees aren't satisfied with communication, their job performance will not be at a satisfactory level. Therefore, the impact of communication on job performance (as one of the outcomes of employees) has been tested in various empirical studies. This has been analyzed in the paper. By search on the Internet, fewer studies have been found that are exclusively dedicated to the impact of communication on job performance compared to the impact of communication on other outcomes of employees (such as job satisfaction, etc.). Communication, productivity, job performance and relationship as the key words have been used. Results confirm that effective communication increases productivity. Also, communication has gained support as a predictor of job performance. However, results confirm a general link between the two variables. In this regard, the purpose of this paper was to provide an insight into communication dimensions, job performance dimensions and the instruments that have been used in important empirical studies. It is found that the impact of communication dimensions on job performance dimensions is unequal. In addition, higher communication satisfaction is not a guarantee of higher job performance (as there are plenty of other factors that affect job performance). This is not to discourage further research into the impact of communication satisfaction on job performance, which has been confirmed by increasing research of this relationship in the companies in developing countries. In the light of this, the paper is expected to stimulate researchers to discuss this topic and motivate further research into the impact of communication on job performance, particularly in Serbian companies and in other similar countries.
\end{abstract}

Keywords: communication satisfaction, productivity, job performance, relationship

\section{UVOD}

Komunikacija, kao jedan od organizacijskih faktora, utiče na organizacione ishode $\mathrm{i}$ ishode zaposlenih od kojih su među značajnijim performanse posla i zadovoljstvo zaposlenih poslom. Zaposleni, a naročito menadžeri, troše mnogo vremena u komunikaciji (pisanoj, usmenoj, formalnoj, neformalnoj, verbalnoj, neverbalnoj, vertikalnoj, horizontalnoj ili bočnoj i dr.). Pretpostavlja se da, ako zaposleni nisu zadovoljni komunikacijom, ni njihove performanse neće biti na zadovoljavajućem nivou, i obrnuto. Zbog toga, u uspešnim organizacijama, menadžeri upravljaju efikasnom komunikacijom, imajući u vidu njene efekte na performanse zaposlenih i druge ishode pojedinaca i organizacije u celini.

$U$ velikom broju empirijskih studija je utvrđeno da je komunikacija u direktnoj vezi sa performansama posla i drugim ishodima zaposlenih. U svojim istraživanjima, autori naglašavaju da i dalje nije popunjena praznina koja je posledica veoma složenog odnosa između zadovoljstva komunikacijom i performansi posla. $\mathrm{U}$ vezi s tim, svrha ovog rada je da prezentuje rezultate važnijih dosadašnjih istraživanja (empirijskih studija) kako bi se stekao uvid u to koje su dimenzije komunikacije i performansi posla korišćene $u$ istraživanjima, odnosno prema kojim instrumentima su procenjivane i da li postoje značajne razlike u rezultatima do kojih su istraživači došli. Ponuđeni pregled empirijskih studija u ovom radu je rezultat pretrage dostupnih studija na Internetu. Pretraga je obavljena kombinacijom ključnih reči komunikacija (communication) i performanse posla (job performance), produktivnost (productivity) i odnos (relationship).

Od ovog rada se očekuje da podstakne istraživače na empirijska istraživanja $u$ ovoj oblasti $u$ preduzećima koja posluju u okruženju kakvo je okruženje Republike Srbije i, njoj, sličnih zemalja. Takođe, ovim radom se žele podstaći menadžeri domaćih preduzeća na procenu zadovoljstva komunikacijom i performansi posla zaposlenih, kao i merenju njihovog međusobnog uticaja.

Rad je strukturiran tako da se drugi deo odnosi na komunikaciju i zadovoljstvo komunikacijom, treći deo na performanse posla i ocenjivanje performansi, četvrti deo na odnos zadovoljstvo komunikacijom - performanse. Slede zaključak i popis korišćene literature. 


\section{KOMUNIKACIJA I \\ ZADOVOLJSTVO KOMUNIKACIJOM}

\subsection{Pojam, uloga i funkcije komunikacije u organizaciji}

Organizacijska komunikacija, kao aktivnost sa namerom, kao namerna razmena ideja, mišljenja i informacija sa ciljnim grupama (Filipović, Kostić i Prohaska, 2001) teži ostvarivanju određenih ciljeva, odnosno rezultata poslovanja. Prema Baziću (2009, p. 41) ona se od drugih oblika komunikacije i razlikuje po tome što teži ostvarivanju poslovnih rezultata. Navedeno implicira da je organizacijska komunikacija svrsishodna aktivnost, a kao takva, ona se planira, usmerava, kontroliše, prilagođava, i menja kako bi se ostvarila ravnoteža između zadovoljstva svih učesnika u komunikaciji, s jedne strane, i uspešnog ostvarenja individualnih i organizacijskih ciljeva, s druge.

$U$ vezi s tim, komunikacija prožima sve faze menadžmenta, tako što podržava primenu procesa planiranja, organizovanja, odlučivanja i kontrole (Borca \& Baesu, 2014, p. 499). Komunikacija, dakle, pomaže efikasnom postavljanju, koliko i ostvarivanju ciljeva organizacije. Ostvarivanje ciljeva organizacije je efikasnije ukoliko kroz komunikaciju pojedinci i grupe koordiniraju svoje aktivnosti radi ostvarivanja radnih zadataka i postizanja postavljenih ciljeva.

Komunikacija vrši određene funkcije unutar organizacije ili unutar grupe. Četiri osnovne funkcije komunikacije su: kontrola, motivacija, emocionalno izražavanje i informisanje (Scott \& Mitchell, 1976 u Robbins \& Judge, 2013, p. 336). Kontrolna funkcija komunikacije služi kontroli ponašanja zaposlenih u grupi ili organizaciji. Komunikacija podiže nivo motivacije zaposlenih tako što im se kroz komunikaciju objašnjavaju zadaci - ono što treba da rade, koliko dobro to rade, i kako mogu eventualno poboljšati svoj rad. Komunikacijom unutar grupe, njeni članovi iskazuju svoje zadovoljstvo ili nezadovoljstvo. Komunikacija na taj način obezbeđuje „emocionalno izražavanje osećanja i ispunjenja socijalne potrebe“. Informaciona funkcija komunikacije čini odlučivanje lakšim i efikasnijim (Robbins \& Judge, 2013, p. 337). Međutim, nema efikasne komunikacije bez interakcije, a ona podrazumeva njenu relacionu ulogu. Kada $u$ odnosu između strana u komunikaciji nema interakcije, onda je i sama dvosmernost, kao primarna odlika efikasne i otvorene komunikacije, diskutabilna. $U$ vezi $s$ tim, smatra se da komunikacija mora biti dvosmerna, uključiti interaktivnost, i za rezultat dati akciju (odluku) kako bi bila efektivna i efikasna (Kalla, 2005, p. 304). Pretpostavlja se da samo efektivna $i$ efikasna komunikacija vode zadovoljstvu zaposlenih komunikacijom i drugim ishodima pojedinaca i organizacije u celini. Zbog toga se u uspešnim organizacijama meri zadovoljstvo zaposlenih komunikacijom.

\subsection{Zadovoljstvo komunikacijom i procena zadovoljstva}

Svaki osećaj zadovoljstva se povezuje sa emocionalnom reakcijom na određene osobe, stvari, dešavanja, događaje, pojave, postignuća i sl. Tako se i zadovoljstvo komunikacijom posmatra kao socio-emocionalni odgovor na interakcije koje se ostvaruju u organizacionoj komunikaciji (Hecht, 1978b u Gray \& Laidlaw, 2004, p. 426).

Zadovoljstvo komunikacijom se može posmatrati jednodimenzionalno i višedimenzionalno. Ukoliko se primeni prvi pomenuti pristup, onda se posmatra ukupno zadovoljstvo komunikacijom. Ukoliko se primeni višedimenzionalni pristup, onda se zadovoljstvo komunikacijom posmatra kao ukupno zadovoljstvo, ali i kao zadovoljstvo njenim pojedinim aspektima (faktorima, dimenzijama). Imajući u vidu višedimenzionalni pristup, u proceni zadovoljstva komunikacijom se koristi više instrumenata (upitnika).

Instrument CSQ (Communications Satisfaction Questionnaire) - upitnik o zadovoljstvu komunikacijom je široko prihvaćen instrument za procenu zadovoljstva komunikacijom. Korišćen je u značajnom broju studija (npr. Pincus, 1986; Clampitt \& Girard 1987; Clampitt \& Girard, 1993; Clampitt \& Downs, 1993; Carriere \& Bourque, 2009; Hadžić, Majstorović i Nedeljković, 2009; Alsayed, Motaghi \& Osman, 2012; Nikolić, Vukonjanski, Nedeljković, Hadžić \& Terek, 2013; Jalalkamali, Ali, Hyun \& Nikbin, 2016). Pomoću CSQ instrumenta, komunikacija se procenjuje kroz svojih osam faktora ili dimenzija. To su: 1) komunikaciona klima 2) komunikacija supervizora (nadređenih) 3) integrisane komunikacije 4) 
kvalitet medija komuniciranja 5) horizontalna neformalna komunikacija 6) opšta pesrpektiva organizacije, odnosno korporativne informacije 7) subordinirajuća komunikacija 8) lične povratne informacije (Downs \& Hazen, 1977, p. 67). Navedene dimenzije komunikacije reprezentuju izvorni oblik upitnika koji se po potrebi nadograđuje, adaptira ili restrukturira prema istraživačkom zadataku, ne menjajući njegovu suštinu, što se pokazalo u nekim empirijskim studijama (npr. Pincus, 1986; Varona, 1996; Alsayed, Motaghi \& Osman, 2012 i dr.). U najvećem broju studija u kojima je korišćen CSQ instrument utvrđeno je da su zaposleni najviše zadovoljni komunikacijom sa nadređenim (supervizorima), a najmanje ličnim povratnim informacijama.

Upitnik OCQ - Organizational Communication Questionnaire je, takođe, jedan od često korišćenih instrumenata u ispitivanju zadovoljstva komunikacijom. I u ovom upitniku komunikacija se posmatra kao složen konstrukt. Čine je dimenzije: 1) poverenje u nadređene 2) uticaj nadređenih 3 ) mobilnost 4) želja za interakcijom 5) komunikacija na gore 6) komunikacija na dole 7) bočna komunikacija 8) tačnost informacija 9) tzv. sumarizacija koja izražava fokus na važne aspekte prenosa informacija 10) zadržavanje informacija 11) preopterećenost informacijama 12) zadovoljstvo komunikacijom (Roberts \& O'Reilly, 1974, p. 323, Table 2).

Više podoban instrument za procenu zadovoljstva komunikacijom je onaj koji se karakteriše multidimenzionalnošću, jer ona daje mogućnost merenja zadovoljstva svakom dimenzijom komunikacije. Korisnost ovog pristupa je upravo u mogućnosti upravljanja komunikacijom i svakom njenom dimenzijom pojedinačno, fokusirajući se na dimenzije kojim zaposleni nisu zadovoljni.

\section{PERFORMANSE POSLA OCENJIVANJE PERFORMANSI}

\subsection{Pojam i vrste perfomansi}

Performanse posla, u opštem smislu, izražavaju rezultate rada. Pojedini autori ih izjednačavaju sa radnim učinkom. Međutim, one su širi pojam od radnog učinka. Kada se odnose na pojedinca onda je reč o individualnim performansama posla, odnosno performansama zaposlenog kao pojedinca, a kada se pod njima podrazumeva suma performansi posla svih zaposlenih onda je reč o performansama zaposlenih u organizaciji. Performanse posla treba razlikovati od poslovnih odnosno organizacionih performansi.

Performanse posla su „agregatni konstrukt napora, veština i ishoda koji su važni za zaposlenog i rezultate koji su važni za firmu" (npr. Behrman \& Perreault 1984; Lusch \& Serpkenci 1990; Walker, Churchill \& Ford 1977 u Christen, lyer \& Soberman, 2006, p. 139). Performanse posla su multidimenzionalan konstrukt. Čine in aspekt ponašanja $\mathrm{i}$ aspekt ishoda (Borman \& Motowidlo, 1993; Campbell, McCloy, Oppler \& Sager, 1993; Roe, 1999 u Sonnentag, Volmer \& Spychala, 2008, p. 427). Ponašanja se odnose na specifična ponašanja zaposlenog tokom obavljanja radnog zadatka koja su neophodna da bi se zadatak obavio, a koja mogu biti verifikovana kao performansa. Ishodi su rezultat koji je posledica navedenog ponašanja zaposlenog. Bez obzira na visok nivo performansi ponašanja (primera radi stručnosti zasposlenog), nivo ishoda može biti nizak (primera radi slaba prodaja), na šta zaposleni ne može uvek da utiče.

Pojedini autori posmatraju performanse kroz nekoliko dimenzija: performanse koje se odnose na sam posao, performanse $u$ vezi sa ponašanjem zaposlenih u organizaciji, performanse u vezi sa kontraproduktivnim ponašanjem i kreativne performanse (Judge \& Kammeyer-Mueller, 2012, p. 357-358)

Performanse zadatka su u uskoj vezi sa obavljanjem posla i određenih zadataka. Bez njih posao ne bi mogao biti odrađen efikasno i efektivno. One se povezuju sa efektivnošću zaposlenog kojom on obavlja svoj posao (Borman \& Motowidlo, 1993 u Borman \& Motowidlo, 1997, p. 99). Uglavnom su formalizovane kroz dužnosti i ponašanja koji su neophodni za radno mesto $i$ radne zadatke (prilagođeno prema Judge \& Kammeyer-Mueller, 2012, p. 357). Dimenzije performansi zadatka su: stručnost koja je specifična za posao, stručnost koja nije specifična za posao, pismena i usmena komunikacija, nadzor (u slučaju da je zaposleni lider) i delimično upravljanje/administracija (Campbell, $1990 \mathrm{u}$ Sonnentag, Volmer \& Spychala, 2008, p. 428). Evidentno da složenošću procene ukupnih performansi doprinosi i činjenica da je svaka pojedina dimenzija performansi takođe sačinjena od više dimenzija. 
Ponašanja zaposlenih u organizaciji, koja su izvan formalnog ponašanja, su $u$ principu ponašanja $u$ datom kontekstu i ponašanja u interpersonalnom odnosu (Judge \& Kammeyer-Mueller, 2012, p. 357). Reč je o kontekstualnom ponašanju, odnosno kontekstualnim performansama. Dimenzije kontekstualnih performansi podrazumevaju dobrovoljne aktivnosti (van obaveznih, formalnih aktivnosti koje su deo posla) i to: istrajnost, entuzijazam i dodatni napor radi uspešnog završetka sopstvenih zadataka, volontiranje u izvršenju aktivnosti koje su van zadatka i koje nisu formalno vezane za svoj posao, pomaganje drugima i saradnja sa njima, poštovanje pravila, propisa i procedura iako mogu biti lično nelagodne, kao i usvajanje, podržavanje i otvoreno branjenje ciljeva organizacije (Borman \& Motowidlo, 1997, p. 102, Table 1).

Performanse zadatka doprinose tehničkom jezgru organizacije, direktno kada su deo tehnološkog procesa ili indirektno kroz obezbeđenje potrebnih materijala ili usluga (Borman \& Motowidlo, $1993 \mathrm{u}$ Borman \& Motowidlo, 1997, p. 99). Kontekstualne performanse su nadogradnja kojom se podržava organizaciono, socijalno i psihološko okruženje (Motowidlo, Borman \& Schmit 1997, p. 75).

Kontraproduktivno ponašanje nije korisno za organizaciju (Ng \& Feldman, 2009, p. 91). Ovakvo ponašanje šteti njenim interesima (Judge \& Kammeyer-Mueller, 2012, p. 357). Obično je posledica neodgovornosti, nemarnosti, nebrige za organizaciju. Lični interesi se stavljaju iznad interesa organizacije i ovakvo ponašanje nije poželjno za organizaciju.

Kreativne performanse su zasebna kategorija performansi (Judge \& Kammeyer-Mueller, 2012, p. 357), i veoma značajna u procesu prilagođavanja organizacije promenama (De Jonge \& De Ruiter, 2004; Johnson, 2000 u Ng \& Feldman, 2009, p. 99).

$\mathrm{U}$ studijama koje su prezentovane $\mathrm{u}$ ovom radu, a u kojima se procenjuje odnos komunikacije i performansi, performanse su ocenjivane na način da nisu vršene procene svake od navedenih dimenzija. Uglavnom je smatrano da su performanse zadatka najvažnija karakteristika ponašanja zaposlenog na poslu. Performanse zadatka su postale sinonim za ukupne performanse.

\subsection{Ocenjivanje performansi}

Od 70-ih godina 20. veka mnogo je pažnje posvećeno faktorima koji utiču na performanse posla, i pojedine indikatore performansi. $\mathrm{Na}$ određene faktore svaki zaposleni može da utiče a to su oni koji se tiču njega samog, njegove ličnosti, obrazovanja, kompetencija, stručnosti i sposobnosti; oni su baza za ispoljavanje volje, ambicioznosti, kreativnosti i proaktivnosti u radu, zalaganju, inventivnosti $i$ inovativnosti. $U$ osnovi ovih faktora se nalazi i motivacija zaposlenog. $\mathrm{Na}$ faktore koji se tiču organizacije, njene strukture i drugih statusnih obeležja zaposleni teško može da utiče ili nikako. Takođe, ne može da utiče na faktore koji deluju iz spoljne sredine organizacije.

U literaturi se navodi da su merila performansi subjektivna i objektivna. Subjektivna merila se odnose na stavove nadređenih ili drugih lica (saradnika, podređenih, ili pripadnika interesne grupe) koja vrše procenu performansi zaposlenog (Ng \& Feldman, 2009, p. 98). Ocenjivač u ovom slučaju treba da je kompetentan, da poseduje potrebne informacije $i$ da ima uvid $u$ rad $i$ ponašanje zaposlenog, njegov odnos prema radu, drugima, samom sebi i organizaciji u celini, da bi što realnije procenio njegove performanse. Takođe, i zaposleni ocenjuju sopstvene performanse. Zaposleni može da ocenjuje i performanse svojih nadređenih. Objektivna mera performansi se odnosi na kvantitativne rezultate rada, u slučaju kada su normirani zadaci. Performanse posla su obično posmatrane kao ukupne, i kroz njihovu kvalitativnu i kvantitativnu dimenziju.

\section{ODNOS ZADOVOLJSTVO KOMUNIKACIJOM PERFORMANSE}

\subsection{Zadovoljstvo komunikacijom - produktivnost}

Performanse posla se ne mogu poistovetiti sa produktivnošću, odnosno moraju se razlikovati od nje (Sonnentag, Volmer \& Spychala, 2008, p. 428), iako produktivnost u sebi sadrži jedan od indikatora performansi a to je učinak zaposlenog iskazan kvantitativno (npr. brojem prozvedenih proizvoda).

Odnos između komunikacije ili zadovoljstva komunikacijom i performansi su ispitivali brojni 
autori, dok je odnos između komunikacije i produktivnosti često bio predmet istraživanja u kojima se paralelno ispitivao i odnos komunikacije i zadovoljstva poslom (npr. Clampitt \& Girard, 1993; Clampitt \& Downs, 1993). Ovi autori su sugerisali da veza između komunikacije i produktivnosti nije jednostavna, i da je treba dalje testirati, što je pobudilo pažnju istraživača. Identifikovano je više pristupa koje su istraživači koristili pri ispitivanju veze između komunikacije i produktivnosti. Jedan od njih uključuje ispitivanje ove veze sa stanovišta zanimanja zaaposlenih, drugi sa stanovišta uticaja komunikacijske prakse na produktivnost organizacije, treći sa stanovišta uticaja dinamike komuniciranja u grupi na produktivnost, četvrti sa stanovišta uticaja komunikacije između nadređenih i podređenih na produktivnost, i peti sa stanovišta uticaja uloge i individualnih veština zaposlenih u komunikaciji na produktivnost (Downs \& Hain, 1982 u Clampit \& Downs, 1993, p. 10). Na kraju, u nekoliko studija je ispitivan uticaj ponašanja u komunikaciji na produktivnost.

Analizom 18 komunikacionih revizija (Clampitt \& Girard, 1993) u kojima je komunikacija uglavnom posmatrana multidimenzionalno (prema CSQ instrumentu) a produktivnost jednodimenzionalno (produktivnost ocenjivanja kroz samoocenjivanje) došlo se do sledećih saznanja: lične povratne informacije su imale najznačajniji uticaj na produktivnost zaposlenih, dok su horizontalna komunikacija, kvalitet medija i korporativna komunikacija-informisanje imali relativno manji uticaj (p. 88). I kasnije je utvrđeno da se pružanjem povratnih informacija podstiče rast zadovoljstva zaposlenih (Phillipe \& Koehler, 2009) čime i performanse. Skoro istovremeno, Klampit i Dauns (Clampit \& Downs, 1993) su ispitivali uticaj dimenzija komunikacije (takođe prema CSQ instrumentu) na produktivnost, i mogući uticaj tipa organizacije kao posrednika u ovoj vezi. Zaposleni su ocenjivali sopstvenu produktivnost i produktivnost nadređenih, dok su nadređeni ocenjivali produktivnost svojih zaposlenih. Saznanja do kojih su došli su da zaposleni nisu jednako percipirali sve dimenzije komunikacije, mada je svaka dimenzija percipirana kao dimenzija koja „iznad proseka“ utiče na produktivnost zaposlenih, da su lične povratne informacije (od nadređenih) imale najjaču vezu sa produktivnošću zaposlenih i to $u$ obe posmatrane organizacije (pp. 20-21). Uočava se da lične povratne informacije imaju najjaču vezu sa produktivnošću. Dakle, različite dimenzije komunikacije različito utiču na produktivnost.

Zanimljiv je rezultat do kog su došli Klampit $i$ Dauns, a to je da su zaposleni različito odredili produktivnost u dve posmatrane organizacije, što i odgovara tipu organizacije. Ovo potvrđuju sledeće činjenice. U organizaciji sektora usluga: $20 \%$ ispitanika je odredilo produktivnost kao količinu svog rada (kvantitativno); 19\% kao obavljanje posla (sposobnost za datu odgovornost); 16\% kroz kvalitet i kvantitet rada; $13 \%$ je svrstalo u kategoriju „zadovoljstvo kupaca", odnosno posmatraju je kroz to koliko su kupci zadovoljni toliko su zaposleni produktivni; $11 \%$ kroz kvalitet rada itd. (Clampitt \& Downs, 1993, p. 16). U drugoj organizaciji - proizvodni sektor, $24 \%$ ispitanika je odredilo produktivnost kao efikasnost korišćenja vremena; po 14\% kroz kvalitet i kvantitet rada; $12 \%$ kroz ostvarenje organizacionih ciljeva i po $10 \%$ kroz kompletan rad tj. odnos kvaliteta i kvantiteta itd. (Clampitt \& Downs, 1993, p. 17). Evidentno je da organizacije u sektoru usluga naglašavaju značaj relacione dimenzije komunikacije i da daju prednost količini rada i sposobnosti za odgovornost u radu u određivanju produktivnosti, dok proizvodni sektor forsira efikasnost korišćenja vremena u obavljanju radnih zadataka. Navedeno ukazuje da uticaj komunikacije na produktivnost zavisi i od vrste delatnosti - tipa organizacije. Autori su, takođe, utvrdili da dizajn posla (radnog mesta) i korisnost informacija za određenu radnu poziciju (top menadžer, nadređeni ili ostali zaposleni), odnosno potreba za specifičnim informacijama prema radnoj poziciji utiču na odnos komunikacija produktivnost. Imajući ovo u vidu, Petit i saradnici (Pettit, Goris \& Vaught, 1997, p. 82) su izneli kritički stav da zadovoljstvo sa određenom dimenzijom komunikacije ne znači nužno i višu produktivnost. $U$ daljim istraživanjima, produktivnost je uglavnom posmatrana kao jedna od kvantitativnih dimenzija performansi.

\subsection{Zadovoljstvo komunikacijom - performanse posla (iskazani različitim indikatorima)}

Ispitivanje uticaja komunikacije na performanse posla se evidentira kao značajna tema u empirijskim istraživanjima od 70-ih godina 20 . 
veka. Već početkom 70-ih godina, obavljeno je ispitivanje $u$ dve bolnice u SAD, a sa ciljem merenja performansi nadređenih prema stavovima podređenih i njihovog odnosa sa određenim varijablama komunikacije (Jain, 1973). Utvrđene su pozitivne veze između 1) efikasnosti komunikacije i performansi 2) količine (i učestalosti) komunikacije i performansi i 3) zadovoljstva komunikacijom i performansi nadređenih. Ocena performansi je uključivala ocenu ljudskih odnosa, administrativnih i tehničkih veština zaposlenih.

Deceniju kasnije, u studiji koja je, takođe, sprovedena u zdravstvu SAD potvrđen je pozitivan odnos komunikacije i performansi posla (testiran je i potvrđen pozitivan uticaj i na zadovoljstvo poslom). Performanse su bile $u$ najjačoj vezi (kao i zadovoljstvo poslom) sa komunikacijom sa nadređenim, te komunikacionom klimom i povratnim informacijama (Pincus, 1986, p. 395). U ovoj studiji je korišćena modifikovana verzija CSQ instrumenta za procenu zadovoljstva komunikacijom kao nezavisne varijable (uključujući tri grupe dimenzija: informacionu, relacionu i informaciono/relacionu) dok su performanse posla bile jedna od dve zavisne varijable.

Komunikacija nadređenih postaje aktuelna istraživačka tema u kontekstu odnosa sa performansama. U studiji, koja je sprovedena $u$ dva preduzeća u SAD, je utvrđeno da poverenje u nadređene $\mathrm{i}$ uticaj nadređenih (kao dimenzije komunikacije prema OCQ upitniku) indirektno utiču na performanse posla (procenjene kroz samoocenu i ocenu nadređenog) preko direktnog uticaja na zadovoljstvo poslom, mada je moderatorni uticaj komunikacije na ovaj odnos slab (Pettit, Goris \& Vaught, 1997, p. 95). Ove dimenzije komunikacije su i prediktori performansi i zadovoljstva poslom u modelu karakteristika posla - JCM modelu (Goris, Vaught \& Pettit, 2003) iz ugla testiranja moderatorne uloge komunikacije. $U$ drugoj studiji ovu podršku je dobila tačnost informacija, kao dimenzija OCQ instrumenta, ali samo kao prediktor kvalitativne dimenzije performansi (Goris, Pettit \& Vaught, 2002). Moderatorna uloga komunikacije i njen uticaj na odnos performanse posla - zadovoljstvo poslom u modelu JCM je, dakle, ispitivana u više studija (videti pregled studija u: Golubović, Milanović i
Bogavac-Cvetković, 2018). U svakoj analiziranoj studiji, komunikacija nije dobila podršku kao moderator, ili je ova podrška bila slaba i odnosila se samo na određene dimenzije komunikacije i uslove kongruencije odnosa rast potreba za razvojem pojedinca - obim posla, ali je dobila neku podršku kao prediktor. Performanse su uglavnom posmatrane kroz njihovu kvalitativnu $\mathrm{i}$ kvantitativnu dimenziju, i kroz njihov zbir, odnosno ukupne performanse. $U$ ovim studijama je utvrđeno da se odnos komunikacije i performansi, odnosno uticaj komunikacije na odnos performanse - zadovoljstvo poslom mora sagledati sa stanovišta radnog mesta i uslova u kojima se podudaraju ili ne podudaraju potrebe pojedinca kao zaposlenog za razvojem (GNS growth need strength) i obim posla (job scope).

Ispitivanje uticaja komunikacije nadređenih na performanse posla postaje aktuelno i sa stanovišta stavova podređenih o komunikaciji nadređenih. $\mathrm{Pa}$, tako je utvrđeno da su performanse zaposlenih pod uticajem nivoa zadovoljstva odnosom sa nadređenim i komunikacijom nadređenih. Zapravo, dobar odnos nadređenih i njegovih podređenih poboljšava performanse zaposlenih (Stringer, 2006, p. 125). Takođe, što je jezik (govor) nadređenog (kao lidera) u komunikaciji više motivacijski, to su bolje performanse njegovih zaposlenih. Potvrđena je pozitivna veza između motivacijskog jezika lidera $\mathrm{i}$ ishoda tj. performansi posla i zadovoljstva zaposlenih poslom (Mayfield, Mayfield \& Kopf, 1998 , p. 241), a naročito kada se ovaj odnos posmatra na nivou diade (odnos lider - sledbenik) (Mayfield \& Mayfield, 2010, p. 407).

$\mathrm{U}$ savremenim uslovima, ispitivanje odnosa komunikacija - performanse se sve više obavlja u preduzećima manje razvijenih zemalja, pa se smatralo ovde značajnim da se navedu rezultati nekih istraživanja. Utvrđeno je da organizaciona komunikacija ima značajan efekat na radne učinke zaposlenih na osnovu sprovedenih istraživanja $u$ raznim organizacijama u Indiji (Giri \& Kumar, 2010), u formalnom sektoru Gane (Abugre, 2011), $u$ bankarskom sektoru Irana (Monavvariana \& Mehdi Asri, 2012), u javnom sektoru - Ministarstvu obrazovanja i zdravlja Palestine (Alsayed, Motaghi \& Osman, 2012), u različitim organizacijama u Lagosu, Nigerija (Femi, 2014), u sektoru hortikulture u Keniji i to posredstvom poboljšane operativne efikasnosti zaposlenih 
(Beryl Achieng Otieno, Wangithi Waiganjo \& Njeru, 2015), u bankarskom sektoru Nigerije, gde je utvrđen značajan efekat komunikacije na dole i komunikacije na gore na performanse zaposlenih (efikasnost i efikasnost) (Nwata, Umoh \& Edwinah, 2016), u preduzećima koja su uključena u međunarodna zajednička ulaganja u Iranu - obe dimenzije zadovoljstva komunikacijom (informaciona i relaciona) su značajno povezane sa performansama zadataka i kontekstualnim performansama (Jalalkamali, Ali, Hyun \& Nikbin, 2016).

Studija (Alsayed, Motaghi \& Osman, 2012) se izdvaja po rezultatima i strukturnoj analizi, te zaslužuje pažnju. Naime, testirane su dimenzije komunikacije prema CSQ instrumentu $i$ to informaciona dimenzija (kvalitet medija, organizaciona perspektiva i organizaciona integracija), relaciona dimenzija (subordinirajuća podređena komunikacija, supervizorska komunikacija i horizontalna komunikacija), informaciono-relaciona dimenzija (lične povratne informacije i komunikaciona klima). Performanse su merene prema ishodima u upitniku Multifactor Leadership Questionnaire od Bass \& Avolio (2000), pri čemu su subjektivni pokazatelji učinka: dodatni napor, zadovoljstvo, efektivnost. Skala performansi zadatka prema Williams \& Anderson (1991) je korišćena za nadređene da bi ocenili aktuelne učinke podređenih. Nalazi su sledeći: informaciono/relaciona dimenzija je najviše uticala na sve indikatore učinka svih podređenih, relaciona dimenzija je u pozitivnom odnosu sa svim dimenzijama osim sa zadovoljstvom sa nadređenim (supervizorom), informaciona dimenzija je u neznačajnom odnosu sa performansama posla. Tri dimenzije zadovoljstva komunikacijom imaju značajan uticaj na pokazatelje učinka zaposlenih (performanse). To su zadovoljstvo nadređenim i odnosima sa njima, povratne informacije i horizontalna neformalna komunikacija. Ukoliko se osvrnemo na sažet prikaz analize prethodnih studija uočavamo da se i u njima ističu povratne informacije i komunikacija sa nadređenima ili odnos sa njima kao dimenzije komunikacije koje se nalaze $u$ jakoj vezi sa performansama.

\section{ZAKLJUČAK}

Pretragom na Internetu, pronađen je značajan broj studija koji su posvećeni uticaju komunikacije na ishode zaposlenih. Manje je novijih empirijskih studija u kojima je jedini istraživački zadatak ispitivanje odnosa zadovoljstvo komunikacijom produktivnost. Takođe je manje empirijskih studija u kojima je jedini istraživački zadatak ispitivanje odnosa zadovoljstvo komunikacijom performanse, kao $\mathrm{i}$ ispitivanje direktnog uticaja komunikacije na performanse. Uglavnom je ispitivan uticaj komunikacije, kao nezavisne varijable, na odnos više zavisnih varijabli od kojih su najčešće zadovoljstvo poslom i perfomanse posla. Drugim rečima ispitivan je indirektni uticaj komunikacije na performanse.

Performanse posla su najpre poistovećivane sa produktivnošću, pa se procenom produktivnosti procenjivao ukupan učinak zaposlenih. Kasnije dolazi do utapanja produktivnosti, kao kvantitativne dimenzije performansi, u njihov agregatni izraz. Opravdano, jer produktivnost čini samo jednu dimenziju performansi. $U$ prezentovanim studijama u ovom radu utvrđena je pozitivna veza između komunikacije i produktivnosti. Faktor ličnih povratnih informacija je imao najznačajniji uticaj na produktivnost zaposlenih. Stoga je veoma važno informisati zaposlene o rezultatima njihovog rada, njihovom mestu i ulozi u ostvarivanju rezultata rada organizacije, odnosno veličini doprinosa uspehu organizacije. Očigledno da su ovakve informacije motivatori zaposlenim na dalji efikasniji $i$ produktivniji rad. Preporučuje se da se neophodno sagleda profil ispitivane organizacije, radnih mesta i pozicija zaposlenih - ispitanika pre nego se pristupi merenju produktivnosti i uticaju zadovoljstva komunikacijom i njenih pojedinih dimenzija na produktivnost. Tumačenje rezultata zahteva da se daju dodatna pojašnjenja shodno navedenoj konstataciji. Generalno, menadžeri moraju redovno da komuniciraju sa zaposlenima da bi poboljšavali njihovu posvećenost i performanse.

Ono što je karakteristično za prezentovane studije, u kojima se vršilo ispitivanje odnosa komunikacija - performanse, je da je ispitivan uticaj dimenzija komunikacije prema različitim instrumentima (CSQ ili OCQ) na ukupne performanse i njihovu kvalitativnu i kvantitativnu dimenziju, pa je poređenje rezultata - uticaja pojedinih dimenzija nešto otežavajuće. Komunikacija sa nadređenim, komunikaciona klima i povratne informacije (prema CSQ 
instrumentu) su u najjačoj vezi sa performansama posla. Drugi pravac karakteriše ispitivanje indirektnog uticaja komunikacije na performanse (uglavnom preko njenog uticaja na zadovoljstvo zaposlenih poslom) kao i njenog uticaja na odnos performanse posla - zadovoljstvo poslom u modelu karakteristika posla - JCM modelu. Rezultati ovakvih ispitivanja ukazuju da je komunikacija dobila podršku kao prediktor performansi u najvećem broju studija, a naročito njene dimenzije kao što su poverenje u nadređene i uticaj nadređenih (prema OCQ instrumentu). Prema LMX teoriji, pozitivan je uticaj motivacionog jezika lidera na performanse sledbenika. Autori prezentovanih studija $u$ ovom radu generalno zaključuju da je veza komunikacije i performansi pozitivna, ali, ili nije značajna, ili je opšta, pa preporučuju dalje testiranje odnosa između ove dve varijable.

lako je uticaj pojedinih dimenzija komunikacije na performanse posla i njihove pojedine dimenzije nejednak, i iako sam porast zadovoljstva komunikacijom ne garantuje rast performansi (jer je veliki broj drugih faktora koji utiču na performanse), ovo ne treba da obeshrabri dalja ispitivanja uticaja zadovoljstva komunikacijom na performanse posla, što je potvrđeno i intenziviranjem ispitivanja ovog odnosa $u$ preduzećima manje razvijenih zemalja. $U$ vezi s tim, od ovog rada se očekuje da pobudi istraživače na diskusiju na ovu temu i motiviše in na istraživanja uticaja komunikacije na performanse posla zaposlenih u preduzećima Republike Srbije.

\section{CITIRANA DELA}

Abugre, J. B. (2011). Appraising the impact of organizational communication on worker satisfaction in organizational workplace. Problems of Management in the 21st century, 1(1), 7-15.

Alsayed, A. K., Motaghi, M. H. \& Osman, I. B. (2012). The Relationship between Communication Satisfaction and Performance Indicators in Palestinian Governmental Organization. International Journal of Scientific and Research Publications, 2(11), 1-9.

Bazić, M. (2009). Poslovna komunikacija - savremeni put do uspeha. Beograd: Megatrend univerzitet.

Beryl Achieng Otieno, B., Wangithi Waiganjo, E. \& Njeru, A. (2015). Effect of Employee Communication on Organisation Performance in Kenya's Horticultural Sector. International Journal of Business Administration, 6(2), 2015, 138-145.

Borca, C. \& Baesu, V. (2014). A possible managerial approach for internal organizational communication characterization. Procedia - Social and Behavioural Sciences, 124, 496-503.

Borman, W. C. \& Motowidlo, S. J. (1997). Task Performance and Contextual Performance: The Meaning for Personnel Selection Research. Human Performance, 10(2), 99-109.

Carriere, J. \& Bourque, C. (2009). The effects of organizational communication on job satisfaction and organizational commitment in a land ambulance service and the mediating role of Communication satisfaction. Career Development International, 14(1), 29-49.

Christen, M., lyer, G. \& Soberman, D. (2006). Job Satisfaction, Job Performance, and Effort: A Reexamination Using Agency Theory. Journal of Marketing, 70 (1), 137-150.

Clampitt, P. G. \& Girard, D. (1987). Time for reflection: Afactor analytic study of the communication satisfaction instrument. Preuzeto sa http://imetacomm.com/wpcontent/themes/Structure\%20Premium\%20White/organic_structure_white/downloads/Metaco mm_FactorAnalytical.pdf (11.3.2018.)

Clampitt, P. G. \& Girard, D. (1993). Communication Satisfaction: A Useful Construct? The New Jersey Journal of Communication, 1(2), 84-102.

Clampitt, P. G. \& Downs, C. W. (1993). Employee perceptions of the relationship between communication and productivity: A field study. International Journal of Business Communication, 30(1), 5-28.

Downs, C. W. \& Hazen, M. D. (1977). A factor analytic study of communication satisfaction. International Journal of Business Communication, 14(3), 63-73.

Femi, A. F. (2014). The Impact of Communication on Workers' Performance in Selected Organisations in Lagos State, Nigeria. IOSR Journal of Humanities and Social Science, 19(8), 75-82. 
Filipović, V., Kostić, M. i Prohaska, S. (2001). Odnosi s javnošću. Beograd: FON.

Giri, N. V. \& Kumar, B. P. (2010). Assessing the impact of organizational communication on job satisfaction and job performance. Psychological Studies, 55(2), 137-143.

Golubović, J., Milanović, V. i Bogavac-Cvetković, N. (2018). Moderatorna uloga komunikacije. Konferencija EMAN 2018, rad prihvaćen (22.3.2018, Ljubljana).

Goris, J. R., Pettit, J. D., JR, \& Vaught, B. C. (2002). Organizational Communication: Is it a moderator of the relationship between job congruence and job performance/satisfaction? International Journal of Management 19(4), 664-673.

Goris, J. R., Vaught, B. C. \& Pettit, J. D., JR. (2003). Effects of Trust in Superiors and Influence of Superiors on the Association Between Individual-Job Congruence and Job Performance/Satisfaction. Journal of Business and Psychology, 17(3), 327-343.

Gray, J. \& Laidlaw, H. (2004). Improving the measurement of communication satisfaction. Management Communication Quarterly, 17(3), 425-448.

Hadžić, O., Majstorović, N. i Nedeljković, M. (2009). Percepcija podrške rukovodioca, dimenzije ličnosti zaposlenih i njihovo zadovoljstvo pojedinim aspektima posla. Psihologija, 42(3), 375-392.

Jain, H. C. (1973). Supervisory Communication and Performance in Urban Hospitals. Journal of Communication, 23(1), 103-117.

Jalalkamali, M., Ali, A. J., Hyun, S. S. \& Nikbin, D. (2016). Relationships between work values, communication satisfaction, and employee job performance: The case of international joint ventures in Iran. Management Decision, 54(4), 796-814.

Judge, T. A. \& Kammeyer-Mueller J. D. (2012). Job Attitudes. Annual Review of Psychology, 63, 341367.

Kalla, H. K. (2005). Integrated internal communications: a multidisciplinary perspective. Corporate Communications: An International Journal, 10(4), 302-314.

Mayfield, J., Mayfield, M. \& Kopf, J. (1998). The Effects of Leader Motivating Language on Subordinate Performance and Satisfaction. Human Resource Management, 37(3-4), 235-248.

Mayfield, J. \& Mayfield, M. (2010). Leader-level influence on motivating language: A two-level model investigation on worker performance and job satisfaction. Competitiveness Review: An International Business Journal, 20(5), 407-422.

Monavvariana, A. \& Mehdi Asri, G. (2012). An empirical study on the relationship between effective organizational communication and the performance of central office staff. Management Science Letters, 2(5), 1549-1554.

Motowidlo, S. J., Borman, W. C. \& Schmit, M. J. (1997). A Theory of Individual Differences in Task and Contextual Performance. Human Performance, 10(2), 71-83.

Ng, T. W. H. \& Feldman, D. C. (2009). How Broadly does Education Contribute to Job Performance. Personnel Psychology, 62(1), 89-134.

Nikolić, M., Vukonjanski, J., Nedeljković, M., Hadžić, O. \& Terek, E. (2013). The impact of internal communication satisfaction dimensions on job satisfaction dimensions and the moderating role of LMX. Public Relations Review, 39(5), 563-565.

Nwata, U. P., Umoh, G. I. \& Edwinah A. (2016). Internal Organizational Communication and Employees' Performance in Selected Banks in Port Harcourt. International Journal of Novel Research in Humanity and Social Sciences, 3(3), 86-95.

Pettit, J. D., JR, Goris, J. R., Vaught, B. C. (1997). An Examination of Organizational Communication as a Moderator of the Relationship Between Job Performance and Job Satisfaction. International Journal of Business Communication, 34(1), 81-98.

Phillipe, T. \& Koehler, J. (2009). Managerial actions that significantly affect employees' perceptions. Journal of Academy of Business and Economics, 5(1), Preuzeto sa http://www.freepatentsonline.com/article/Journal-Academy-BusinessEconomics/149213880.html (13.3.2018.) 
Pincus, D. (1986). Communication satisfaction, job satisfaction, and job performance. Human Communication Research, 12(3), 395-419.

Robbins, S. P. \& Judge, T. A. (2013). Organizational Behaviour. 15 th ed. New Jersey: Pearson Education.

Roberts, K. H. \& O'Reilly, C. A. (1974). Measuring organizational communication. Journal of Applied Psychology, 59(3), 321-326.

Sonnentag, S., Volmer, J. \& Spychala, A. (2008). Job Performance. In The Sage Handbook of Organizational Behavior, vol. 1 - Micro Perspectives (ed. by Cooper, C. L., Barling, J.). Los Angeles, California: SAGE, 427-447, Preuzeto sa https://www.unibamberg.de/fileadmin/uni/fakultaeten/ppp_lehrstuehle/organisationspsychologie/Publikationen _JV/Sonnentag_Volmer_Spychala_Job_Performance_2008.pdf (10.3.2018).

Stringer, L. (2006). The link between the quality of the supervisor-employee relationship and the level of the employee's job satisfaction. Public Organization Review, 6(2), 125-142.

Varona, F. (1996). Relationship between communication satisfaction and organizational commitment in three Guatemalan organizations. International Journal of Business Communication, 33(2), 111140.

\section{NAPOMENA}

Ovaj rad je podržan od strane Ministarstva prosvete, nauke i tehnološkog razvoja Republike Srbije (projekat III 45003)

Datum prve prijave:

14.03.2018.

Datum prijema korigovanog članka: 23.07 .2018 .

Datum prihvatanja članka:

05.09.2018

Kako citirati ovaj rad? / How to cite this article?

Style - APA Sixth Edition:

Milanović, V., Bogavac-Cvetković, N., \& Bogavac, M. (2018, 10 15). Komunikacija i performanse posla. (Z. Čekerevac, Ur.) FBIM Transactions, 6(2), 62-72. doi:10.12709/fbim.06.06.02.07

Style - Chicago Sixteenth Edition:

Milanović, Vesna, Nataša Bogavac-Cvetković, i Milanka Bogavac. 2018. „Komunikacija i performanse posla." Urednik Zoran Čekerevac. FBIM Transactions (MESTE) 6 (2): 62-72. doi:10.12709/fbim.06.06.02.07.

Style - GOST Name Sort:

Milanović Vesna, Bogavac-Cvetković Nataša i Bogavac Milanka Komunikacija i performanse posla [Časopis] // FBIM Transactions / ur. Čekerevac Zoran. - Beograd : MESTE, 1510 2018. - 2 : T. 6. - str. 62-72.

Style - Harvard Anglia:

Milanović, V., Bogavac-Cvetković, N. \& Bogavac, M., 2018. Komunikacija i performanse posla. FBIM Transactions, 15 10, 6(2), pp. 62-72.

Style - ISO 690 Numerical Reference:

Komunikacija i performanse posla. Milanović, Vesna, Bogavac-Cvetković, Nataša i Bogavac, Milanka. [ur.] Zoran Čekerevac. 2, Beograd : MESTE, 1510 2018, FBIM Transactions, T. 6, str. 6272. 